International Journal of Social Sciences and Humanities
Available online at www.sciencescholar.us
Vol. 5 No. 3, December 2021, pages: 253-263
e-ISSN: 2550-7001, p-ISSN: 2550-701X
https://doi.org/10.53730/ijssh.v5n3.2025

\title{
Analysis of Cooperative Learning in Adolescents with Attention Deficit
}

\author{
CrossMark \\ Fernando Eduardo Cornejo Rivas a, Marilyn Lidia Basurto Pilligua ${ }^{\text {b }}$, Jacqueline Aracely Arteaga \\ Guerrero ${ }^{c}$, José Atilio Murillo Moreira ${ }^{\mathrm{d}}$, María José Zambrano Zambrano ${ }^{\mathrm{e}}$
}

Manuscript submitted: 27 September 2021, Manuscript revised: 09 October 2021, Accepted for publication: 18 November 2021

Corresponding Author ${ }^{\text {a }}$

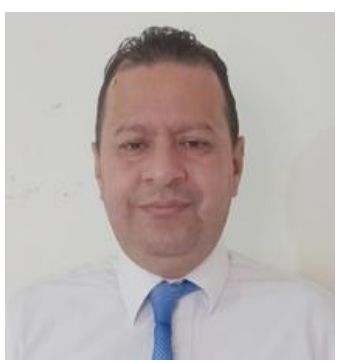

Keywords

cooperative;

disorders;

personality;

social;

students

\section{Abstract}

This research is considered in the field of cooperative and social learning for a better development of interpersonal relationships in tasks that are carried out together, considering the level of understanding and understanding of each of the people who make up the team. It focuses on adolescents with attention deficit cases, considered in all types of work, whether individual or group, without being discriminated against for suffering from this type of disorder. Different techniques have been implemented that seek to involve both children and adolescents in teamwork, where each of them, despite their personal problems or inconveniences, must carry out their assigned task and carry out productive work. Those who suffer from hyperactivity, attention deficit and other types of disorders, must have the support of the society to which they are exposed, where they must find a way to fit in and be understood by family, friends, colleagues, etc., they also play a game. Fundamental role in the treatment of personality. It seeks to provide options such as cooperative learning in educational institutions, they must implement this type of teaching in order to facilitate the learning of students with personality problems.

International Journal of Social Sciences and Humanities (C) 2021. This is an open access article under the CC BY-NC-ND license (https://creativecommons.org/licenses/by-nc-nd/4.0/).

\section{Contents}

Abstract

\footnotetext{
a Master's Degree in Educational Innovation, Pontificia Universidad Católica del Ecuador, Sede Manabí, Portoviejo, Ecuador

Master's Degree in Educational Innovation, Pontificia Universidad Católica del Ecuador, Sede Manabí, Portoviejo, Ecuador Master's Degree in Educational Innovation, Pontificia Universidad Católica del Ecuador, Sede Manabí, Portoviejo, Ecuador

Master's Degree in Educational Innovation, Pontificia Universidad Católica del Ecuador, Sede Manabí, Portoviejo, Ecuador

Master's Degree in Educational Innovation, Pontificia Universidad Católica del Ecuador, Sede Manabí, Portoviejo, Ecuador
} 


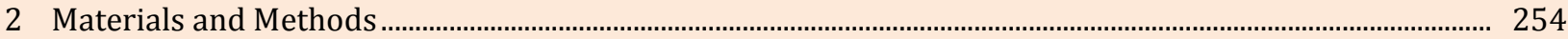

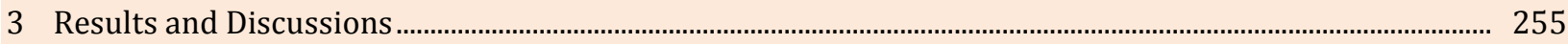

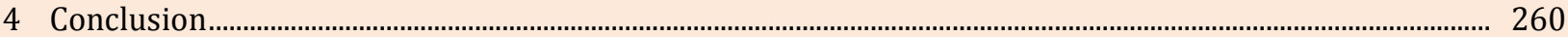

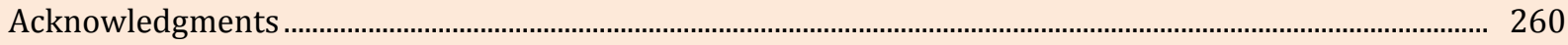

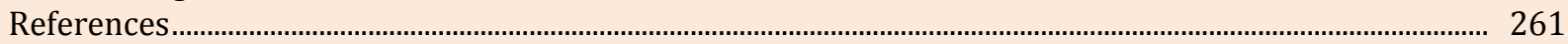

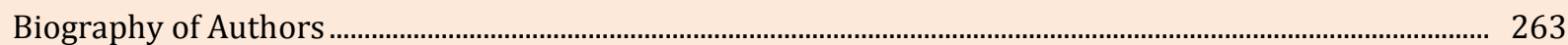

\section{Introduction}

Towards the middle of the last century, a growing interest arose in the United States to give a pedagogical response to a situation that was turning school classrooms, especially those of secondary education, into places that were not suitable for developing the main task for which they had been created. That is, to guarantee the education of the children and young people who attended them (Gómez, 2007). Cooperative learning, also called work in cooperative groups, is a distinctive form of group work that is characterized by the fact that groups approach the resolution of the same task or problem working together (Lara Villanueva, 2005). This task is tackled by colleagues who are at a similar or slightly different level of knowledge and, due to joint action, the results achieved are different from those that would be achieved if each of its members worked individually. This is why in cooperative work the contribution of each of its members is relevant (Denegri Coria et al., 2007).

The demographic and human reality meant that heterogeneity had become one of the main characteristics of these educational environments. Heterogeneity and diversity that translated into classrooms full of boys and girls from very diverse racial backgrounds, with disparate educational levels, with interests and motivations barely coinciding and in which teachers tried to solve teaching-learning situations (Azorín Abellán, 2018). Faced with this educational scenario, a large group of researchers began to study, experiment and design a set of didactic techniques that aim to consolidate quality learning processes through mediated, interactive and collaborative processes (García et al., 2019). It was the beginning of what is known today as cooperative learning, thus being the beginning of a new conceptualization of the instructive processes in which the possibility of giving answers to school situations that had begun to generate a state of discouragement among different sectors is perceived (Fischbacher et al., 2001; Thomson, 1994).

Cooperative learning is the didactic use of small groups in which students work together to maximize their own learning and others (Azorín Abellán, 2018). This method contrasts with competitive learning, in which each student works against others to achieve school goals, such as a "score of 10", which only one or a few can obtain, and with individualistic learning, in which students work alone. to achieve learning, disconnected from those of other students (Johnson et al., 1999). It is a syndrome of enormous dimensions, which reaches a large number of facets and should be called "Attention Deficit and Hyperactivity Syndrome (SDAHA) with much more property than ADHD (Pascual-Castroviejo, 2008). The attention deficit is mainly characterized by the difficulty to pay attention to routine activities, which causes difficulties in the daily life of the person who suffers from them and significantly impairs their academic and personal development. It should be taken into account that these Symptoms appear from childhood (Sancho Balarezo, 2017).

\section{Materials and Methods}

The methodology used is based on the inductive-deductive analysis that will help the interpretation of the processes for the analysis of cooperative learning in adolescents with attention deficit, the basic modality of the research is descriptive that will help the scientific support of the learning analysis cooperative. The exploratory methodology and the bibliographic documentary were used where the different approaches, theories, conceptualizations and criteria of different authors were known, compared, expanded, deepened and deduced the different approaches, theories, conceptualizations and criteria of various authors based on documents, books, publications in reliable scientific databases, among which They host high-impact scientific journals that helped enrich the theoretical part of the research work (Torgersen et al., 2000; Warren et al., 1997). 


\section{Results and Discussions}

The AC is defined as a successful strategy or a set of instructional methods, it allows working with small groups of students where each one contributes with their contributions, students of different levels and abilities can intervene here, and this technique allows to expand the learning capacity and improves understanding of the subject (Lara Villanueva, 2005). AC is one of the methodological strategies used in education worldwide, its application has been the subject of several investigations due to its effectiveness in achieving academic success, with the affective, cognitive, and social development of students. This type of tool represents one of the educational practices that have been implemented with the most success in recent decades. Its use has shown a marked difference between alternative practices to traditional teaching. The contributions that have been able to respond to the different needs presented by individuals in the 21st century is valued (Azorín Abellán, 2018).

The work of the students is evaluated by the teachers according to certain criteria, here we can find the competitive one, where the students are classified according to the rules that apply. The existence of individualistic limitations on when and how to use them correctly must be considered, this allows the teacher to cooperate in any didactic and pedagogical task and within any study plan (Johnson et al., 1999). There are four types of learning groups that can be formed in a classroom setting see figure 1.

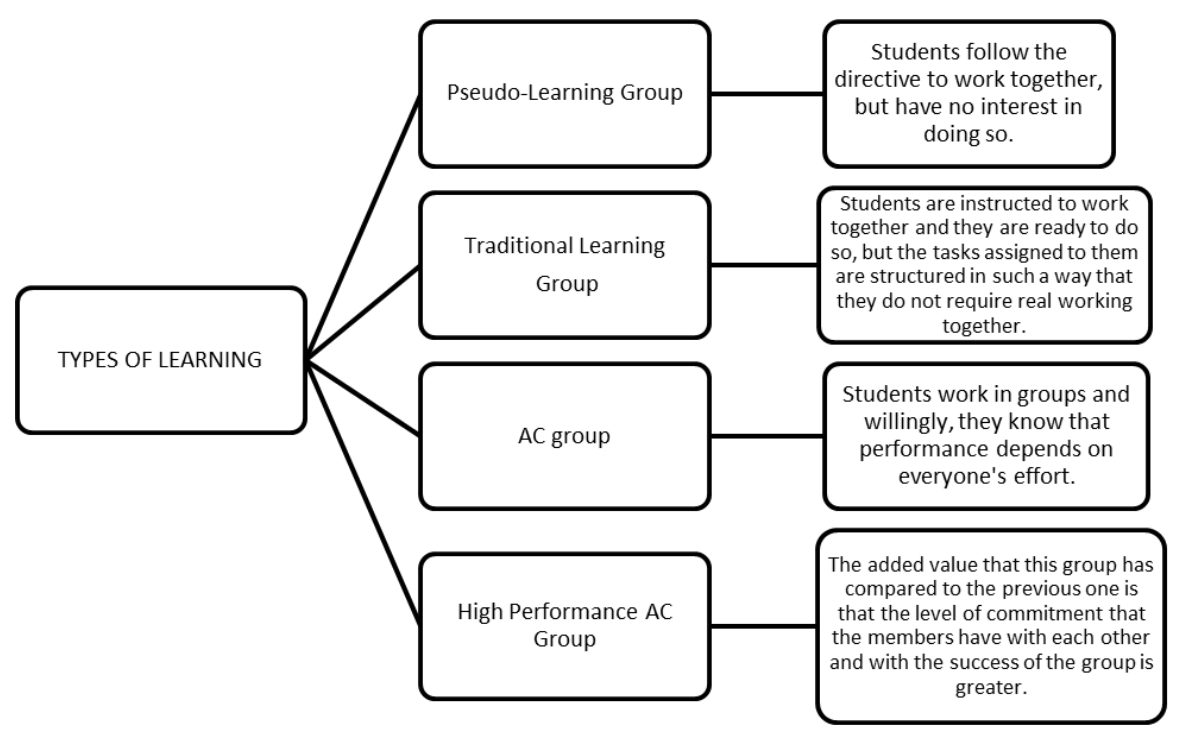

Figure 1. Types of learning groups

Source: (Domingo, 2008)

1. The pseudo-learning group: in this case, the students follow the directive to work together, but have no interest in doing so. They believe that they will be evaluated according to the score assigned to their individual performance. Although they appear to be working together, they are competing. Each student sees the others as rivals to defeat, so they all hinder or interrupt the work of others, withhold information, try to confuse each other, and have a mutual distrust. Therefore, the sum of the total is less than the potential of the individual members of the group. Schoolchildren would work better individually.

2. The traditional learning group: students are instructed to work together, and they are ready to do so, but the tasks assigned to them are structured in such a way that they do not require true joint work. Students think that they will be evaluated and awarded as individuals, and not as members of the group. They only interact to clarify how tasks should be carried out. They exchange information but are not motivated to teach their teammates what they know. The predisposition to help and share is minimal. Some students let themselves be, waiting to take advantage of the efforts of their more

Rivas, F. E. C., Pilligua, M. L. B., Guerrero, J. A. A., Moreira, J. A. M., \& Zambrano, M. J. Z. (2021). Analysis of cooperative learning in adolescents with attention deficit. International Journal of Social Sciences and Humanities, 5(3), 253-263. https://doi.org/10.53730/ijssh.v5n3.2025 
responsible peers. Group members who are more responsible feel exploited and don't try as hard as usual. The result is that the sum of the total is greater than the potential of some of the members of the group, but the hardworking and responsible students would work better alone.

3. The cooperative learning group: students are instructed to work together, and they do so willingly. They know that their performance depends on the effort of all the members of the group. Groups of this type have five distinctive characteristics. The first is that the group objective of maximizing the learning of all members motivates students to strive and obtain results that exceed the individual capacity of each of them. The members of the group are convinced that they will all sink or float together, and that if one of them fails, then they all fail. Second, each member of the group takes responsibility, and holds others accountable, for doing a good job to meet common goals. Third, group members work side by side to produce joint results. They do a true collective work and each one promotes the good performance of the others, by helping, sharing, explaining, and encouraging each other. Support is provided, both school and personal, based on mutual interest and commitment. Fourth, group members are taught certain forms of interpersonal relationship and are expected to use them to coordinate their work and achieve their goals. Teamwork and task execution are emphasized, with all members taking responsibility for leading the process. Finally, the groups analyze how effectively they are achieving their goals and to what extent members are working together to ensure sustained improvement in their learning and teamwork. Therefore, the group is more than the sum of its parts, and all students perform better than if they had worked alone.

4. The high-performance cooperative learning group: This is a type of group that meets all the criteria required to be a cooperative learning group and, in addition, achieves returns that exceed any reasonable expectation. What sets the cooperative learning group apart is the level of commitment members have to each other and to the success of the group. Each member's interest in the personal growth of others makes it possible for these high-performing cooperative groups to exceed expectations, and for their members to enjoy the experience. Unfortunately, although it is understandable, high-performance groups are very rare, because most do not reach this level of development (Johnson, Johnson, \& Holubec, 1999).

To ensure that student learning is equitable, different authors have proposed cooperative learning techniques, where it is a wide and heterogeneous set of structured instructional methods in which students work together, in groups or teams, helping each other on tasks. Generally academic (Barrachina \& Torrent, 2010). In this methodology different techniques are used such as:

\section{Aronson's puzzle technique}

It is one of the most used or representative of the classroom, an interdependence is created between students, because they are divided between all the learning tasks and structure of the interactions between them through work teams with the same objectives and resources, where they depend on each other to achieve their goals. With this, it is possible to establish cooperation between its members in work groups through the division of tasks so that interdependence is guaranteed as a tutor of the students (García et al., 2019).

\section{Game-contest De Vries technique}

Also known as "Learning Tournaments" or "De Vries Game-Contest". Based primarily on cooperation, this technique also combines competitive elements, since at one point in its development, heterogeneous groups will compete. It is about students learning to compete among themselves in a "healthy" way, through cooperative work. It offers the advantage of being able to work on subject content in a fun way while learning to improve their interpersonal relationships, to better integrate into the group, to recognize and value the efforts made by each of the team members, etc (Barrachina \& Torrent, 2010).

Share with cooperative learning techniques the following four elements: positive interdependence, face-toface interaction with students, individual responsibility and the use of interpersonal group members and group skills. This technique was initially devised by Vries and Edwards in 1,973 and later perfected. It offers the advantage of being able to work on subjects with fun while learning to improve their interpersonal 
relationships, be better integrated in the group, recognize, and evaluate the efforts made by each of the team members, etc. There is sufficient empirical evidence that this technique gave positive results in the development of attitudes (García et al., 2019).

\section{Research group technique}

It is a general organization plan for the class, in which students work in small groups using cooperative inquiry, group discussion, projects, and planning. A unit that must be studied in the whole class, it is subdivided into topics. Each group turns these topics into individual tasks and performs the necessary activities to prepare the group report. Then, each group makes a presentation to communicate their discoveries to the class (García et al., 2019).

\section{Cooperative learning conditions}

In general, cooperative ecological proposals will accentuate the functionality of work organization and social relationships, in which more complex roles are needed than in normal or traditional class situations. The composition of the groups does not depend on the previous relationship that they could have had, but also on the properties of the activity and the search for the greatest possible heterogeneity. The organization of the task in a structure in which it implies interdependence, in which it offers a real importance of the form of social organization and the actions of the different people within the group. The heterogeneity of the group constitutes the guarantee that conflicts or controversies can be generated, a key element in causing the expiration of its members, from the point of view of the development of tolerance and a critical spirit. Therefore, it is a direct loan of progress in the members of the group. Similarly, the number of members is since everyone can intervene correctly and that optimal levels of interaction are provided (García et al., 2019).

\section{Characteristics}

Cooperative learning its characteristics:

1. High degree of equality: There must be symmetry in the roles played by the participants of a group activity.

2. Variable degree of mutuality: Mutuality is the degree of deep and bi-directional interconnection of communication opportunities. High levels of mutuality will be promoted when planning is carried out in the discussion with the participants of the group work, where the exchange of roles is coordinated and a union between the team members is delimited by their subsequent division of activities (Prenda, 2011).

\section{Attention déficit}

It is a syndrome of enormous dimensions, which reaches a large number of facets and should be called "Syndrome of Attention Deficit and Hyperactivity (SDAHA) with much more property than ADHD. In recent years, a series of comorbid disorders have become increasingly important, whose presence or not will play a much more decisive role on treatment and prognostic consequences for individuals than the three fundamental symptoms (Pascual-Castroviejo, 2008).

Although it has always been known throughout the history of humanity that the scientific bases of knowledge and its clinical peculiarities were established at the beginning of the 20th century. Before arriving at the current denomination of "syndrome of attention deficit and hyperactivity", almost unanimously accepted, it received diverse scientific names such as "minimal brain damage" and "minimal brain dysfunction". However, at the level of the language of the street, the people who suffered from the picture were known as "bad-seat asses", "weather vanes", "light heads", "lost sheep", "crazy heads" and similar names (Pascual-Castroviejo, 2008). Attention deficit hyperactivity disorders (ADHD) are defined by the presence of three fundamental symptoms observed in Figure 2.

Rivas, F. E. C., Pilligua, M. L. B., Guerrero, J. A. A., Moreira, J. A. M., \& Zambrano, M. J. Z. (2021). Analysis of cooperative learning in adolescents with attention deficit. International Journal of Social Sciences and 


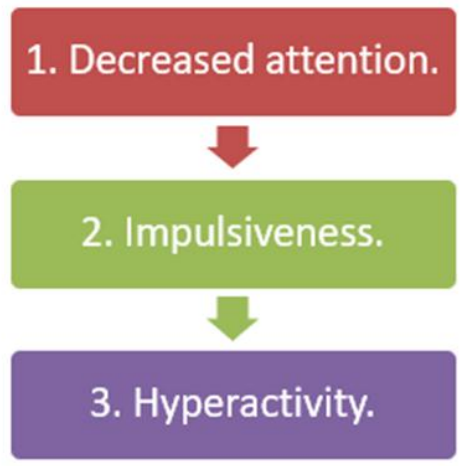

Figure 2. Fundamental symptoms of attention deficit. Source: (Pascual-Castroviejo, 2008)

1. Decreased attention; their continuous evasion and disorganization in spaces and times, as well as their inability to select information, are noted in them. Three types of attention are distinguished within the behavioral and cognitive process of the student: attention alert (focus); previous attention (sustained attention), this being the dysfunctional capacity in children with ADHD; and aftercare or review.

2. Impulsiveness or lack of inhibition: The student shows challenging behaviors, agitation, competitiveness, and persistent interests.

3. Hyperactivity or excessive motor activity: which is reflected in the exorbitant motor activity shown by the boy and / or girl. Extreme curiosity also stands out.

\section{Classification and subtypes}

At present there are 2 international classification systems that have been converging over time, although there are still differences:

1. The DSM-IV (Statistical Diagnostic Manual of Mental Illness of the American Psychiatric Association). It describes 3 subtypes depending on the symptoms that are present:

1. Subtype with inattentive predominance (when there is only inattention). Between $20-30 \%$ of cases

2. Subtype with hyperactive-impulsive predominance (when there is only hyperactivity and impulsivity) of $10-15 \%$, questioned by some authors

3. Combined subtype (when all 3 types of symptoms are present). From $50-75 \%$ of cases.

2. The ICD-10 (WHO International Classification of Mental Illness). According to this, the simultaneous existence of the 3 types of symptoms is necessary: attention deficit, hyperactivity and impulsivity, constituting the picture of "alteration of activity and attention". It also recognizes a separate category, "hyperkinetic behavior disorder" when they coincide, in addition to the 3 symptoms, an alteration of behavior. In this way, with the ICD-10, being the most restrictive criteria, fewer pictures are diagnosed than with the DSM-IV (Hidalgo \& Soutullo, 2014).

\section{Special needs in adolescents}

Most children who suffer from ADHD continue to develop symptoms as they enter youth, but some are not diagnosed with ADHD until they communicate with adolescence. This is more common in children with symptoms of a predominantly inactive nature, because they do not necessarily have discipline problems at home or at school, in these children the tumult becomes fiercer because academic requirements increase and responsibilities accumulate. For all young people, this phase is challenging, but for young people suffering from TADH, these years can be particularly difficult. Although hyperactivity tends to decrease as the child grows up, teens who remain hyperactive may be restless and try to do too many things at the same time, they may choose tasks or activities that offer immediate benefits, rather than those that require more effort but offer long-term rewards. Teens who are primarily due to attention deficit have problems with school and other activities in which they should be more independent. Young people are also responsible for the 
decisions they make about their own health for a child with ADHD parents are more likely to be responsible for the fact that the child continues with treatment, but if the child's parents do not control and may have problems after treatment. Teens with or without ADHD want to be independent and try new things and sometimes, they're going to break the rules. If the adolescent breaks the rules, the response of the parents should be as calm and natural as possible, the punishment should be used only rarely. Teens with ADHD frequently have trouble controlling their impulsivity and may have strong fits of anger, sometimes a brief "time out" can calm them (National Institute of Mental Health) down (Furnham et al., 1999; ChamorroPremuzic et al., 2007).

\section{Conflicts in the school and community}

In this category, parents reported situations of violence in the school context and fights in the street, with the participation of teachers, students, friends, and strangers (Athilakshmi \& Chitra, 2018; Meza et al., 2020). Parents described that, in the context of school, children were not understood, and they did not receive support from teachers or leaders. They suffered discrimination, were excluded, and considered mentally ill, lazy, or vagabond. They were held accountable for what others did. Their children, in turn, presented aggressive behaviors both verbally and physically with classmates and teachers, contributing to segregation and even expulsion from school. On the other hand, the parents reported that the children suffered, showed the difficulty of adapting to school with somatic symptoms (vomiting, fever) and had no stimulus to study, resulting in disinterest and school dropout (Kennedy et al., 1998; Stiller \& Dunbar, 2007).

\section{Cooperative learning in adolescents \\ Advantages in the classroom}

Among the benefits of the AC according to Domingo (2008), it stands out that students are involved in their own learning process, are involved with the subject of study and with their peers, and increase the level of learning through interaction. In this line, Slavin (1991) explains that by applying the cooperative learning method, performance and interpersonal relationships are improved, thinking skills are developed and collaboration skills are increased. Other works reveal its influence on the improvement of the academic, personal and social development of students (Pérez-Sánchez \& Poveda-Serra, 2008). Obviously, when this method is used, what is sought is to break with the traditional individualism of learning that since ancient times has been exercised in education Blanco (2009), as well as to reduce exclusionand violence, thereby improving school coexistence in the classroom (Díaz-Aguado, 2006). In this regard, Johnson \& Johnson (2000) state that cooperative learning is a tool that improves relationships between diverse groups of students and provides greater interpersonal attraction (Azorín Abellán, 2018).

\section{Cooperative learning techniques as inclusive tools}

Understood as a learning tool applicable to educational environments, Information and Communication Technologies (ICT) have come to be considered as Learning and Communication Technologies (TAC), and refer to the use that students make of this medium to improve their learning (Archer, 2014; LatorreCosculluela et al., 2018). TACs have been consolidated, for a relatively short time, as an essential part of education and, more specifically, of special education (Tan \& Cheung, 2008). Given the increasing use of computer technologies in the classroom since the early stages of schooling, educational responses based on this type of support have been progressively introduced (Archer, 2014; Rabiner, Murray, Skinner \& Malone, 2010; cited in (Latorre-Cosculluela et al., 2018).

The AC is positive for all students since it favors a greater degree of socialization with their peers and significantly increases their work capacity and acquired knowledge. In any case, it is necessary to consider a series of aspects that prevent this method, in principle so beneficial for everyone and - especially - for children with special educational needs, from ending up being one more way to cover up the school marginalization to which this type of students is subjected on many occasions. This methodology requires great involvement on the part of the teacher. Undoubtedly, the work he must do is much greater than that of the teacher who simply follows a textbook from which he becomes a slave. The AC implies another vision of

Rivas, F. E. C., Pilligua, M. L. B., Guerrero, J. A. A., Moreira, J. A. M., \& Zambrano, M. J. Z. (2021). Analysis of cooperative learning in adolescents with attention deficit. International Journal of Social Sciences and Humanities, 5(3), 253-263. https://doi.org/10.53730/ijssh.v5n3.2025 
the teacher, a true professional who really directs his class, the contents to be treated and the way to do it. In addition, he ceases to be the center of attention and the watchman, to share these functions with the students, who are now themselves who control themselves and, in addition, supervise the work of the classmates (Garg et al., 2001; Kowalski \& Limber, 2007). Of course, if the method works correctly, the teacher can devote much more time to work on the preparation of the work material, since the order in the class is ensured thanks to the cooperation of his students. However, it is possible that some variables prevent this. Students with special educational needs may feel motivated to work as a team, but if the topics they try, aren't interested, or feel like they always get the easiest role in their group, they'll end up thinking about the place in their class. On the other hand, if teachers don't have the sensitivity and patience needed to work with these types of people, the advantages of cooperative learning that all the research showed can never be achieved (Bernal, 2009).

\section{Conclusion}

There are cases where adolescents feel discriminated against and / or excluded from the way in which teachers perform their task of teaching and learning to students, who have a unique form of pedagogy and should look for alternatives related to either ICTs and include them in their teaching plan, so that all students in charge can understand and understand the subject taught. Adolescents with attention deficit need understanding from civil society, both teachers, friends, peers, and family, who are responsible for helping the child and adolescent to carry their personality issue in a more practical and easy way with society.

Acknowledgments

We are grateful to two anonymous reviewers for their valuable comments on the earlier version of this paper. 


\section{References}

Archer, C. (2014). International organizations. Routledge.

Athilakshmi, V., \& Chitra, S. (2018). College student attitude towards social media. International Research Journal of Management, IT and Social Sciences, 6(1), 33-41. https://doi.org/10.21744/irjmis.v6n1.481

Azorín Abellán, C. M. (2018). El método de aprendizaje cooperativo y su aplicación en las aulas. Perfiles educativos, 40(161), 181-194.

Barrachina, L. A., \& Torrent, M. S. (2010). El juego-concurso de DeVries: una propuesta para la formación en competencias de trabajo en equipo en la evaluación. REDU: Revista de Docencia Universitaria, 8(1), 121141.

Bernal, M. T. (2009). Ventajas del aprendizaje cooperativo para la socialización de los alumnos con necesidades educativas especiales. Revista interuniversitaria de formación del profesorado, (65), 137-150.

Blanco, M. I. (2009). The economics of wind energy. Renewable and sustainable energy reviews, 13(6-7), 13721382.

Chamorro-Premuzic, T., Bennett, E., \& Furnham, A. (2007). The happy personality: Mediational role of trait emotional intelligence. Personality and individual differences, 42(8), 1633-1639. https://doi.org/10.1016/j.paid.2006.10.029

Denegri Coria, M., Opazo Pino, C., \& Martínez Toro, G. (2007). Aprendizaje cooperativo y desarrollo del autoconcepto en estudiantes chilenos. Revista de pedagogía, 28(81), 13-41.

Díaz-Aguado, M. J. (2006). Del acoso escolar a la cooperación en las aulas. Pearson/Prentice Hall.

Domingo, J. (2008). El aprendizaje cooperativo. Cuadernos de trabajo social, 21, 231-246.

Fischbacher, U., Gächter, S., \& Fehr, E. (2001). Are people conditionally cooperative? Evidence from a public goods experiment. Economics letters, 71(3), 397-404. https://doi.org/10.1016/S0165-1765(01)00394-9

Furnham, A., Forde, L., \& Ferrari, K. (1999). Personality and work motivation. Personality and individual differences, 26(6), 1035-1043. https://doi.org/10.1016/S0191-8869(98)00202-5

García, R., Traver, J., \& Candela, I. (2019). Aprendizaje Cooperativo fundamentos, características y técnicas Aprendizaje Cooperativo.

Garg, A. X., Norman, G., \& Sperotable, L. (2001). How medical students learn spatial anatomy. The lancet, 357(9253), 363-364. https://doi.org/10.1016/S0140-6736(00)03649-7

Gómez, J. (2007). Aprendizaje cooperativo: metodología didáctica para la escuela inclusiva. La Salle.

Hidalgo, I., \& Soutullo, C. (2014). Trastorno por déficit de atención e hiperactividad (TDAH). 3-22. Madrid, España.

Johnson, DW, Johnson, RT, \& Holubec, EJ (1999). The cooperative learning in the classroom.

Johnson, G. J., \& Johnson, W. R. (2000). Perceived overqualification and dimensions of job satisfaction: A longitudinal analysis. The journal of psychology, 134(5), 537-555.

Kennedy, B. P., Kawachi, I., Prothrow-Stith, D., Lochner, K., \& Gupta, V. (1998). Social capital, income inequality, and firearm violent crime. Social science \& medicine,47(1), 7-17. https://doi.org/10.1016/S02779536(98)00097-5

Kowalski, R. M., \& Limber, S. P. (2007). Electronic bullying among middle school students. Journal of adolescent health, 41(6), S22-S30. https://doi.org/10.1016/j.jadohealth.2007.08.017

Lara Villanueva, RS (2005). Cooperative Learning: An Intervention Model for Higher Level School Tutoring Programs. Rev. educ. sup , 87-104.

Latorre-Cosculluela, C., Liesa-Orús, M., \& Vázquez-Toledo, S. (2018). Inclusive schools: cooperative learning and TAC with students with ADHD (No. ART-2018-106565).

Meza, W. E. Y., Saltos, E. R. R., Loor, B. M. V., \& Solorzano, M. J. P. (2020). Technological tools as didactic resource for various educational modalities. International Research Journal of Management, IT and Social Sciences, 8(1), 9-18. https://doi.org/10.21744/irjmis.v8n1.1079

Pascual-Castroviejo, I. (2008). Attention deficit hyperactivity disorder (ADHD). Spanish Association of Pediatrics and Spanish Society of Pediatric Neurology. Neurology Protocols , 12 , 140-150.

Pérez-Sánchez, A. M., \& Poveda-Serra, P. (2008). Efectos del aprendizaje cooperativo en la adaptación escolar. Revista de Investigación educativa, 26(1), 73-94.

Prenda, N. P. (2011). El aprendizaje cooperativo y sus ventajas en la educación intercultural. Hekademos: Revista educativa digital, (8), 63-76.

Rivas, F. E. C., Pilligua, M. L. B., Guerrero, J. A. A., Moreira, J. A. M., \& Zambrano, M. J. Z. (2021). Analysis of cooperative learning in adolescents with attention deficit. International Journal of Social Sciences and Humanities, 5(3), 253-263. https://doi.org/10.53730/ijssh.v5n3.2025 
Sancho Balarezo, G. V. (2017). Estrategias metodológicas para disminuir el déficit de atención en el proceso de enseñanza aprendizaje en el sexto año de educación básica en la escuela Federico Proaño de la parroquia Bellavista, cantón Cuenca en el periodo lectivo 2016-2017 (Bachelor's thesis).

Slavin, R. E. (1991). Synthesis of research of cooperative learning. Educational leadership, 48(5), 71-82.

Stiller, J., \& Dunbar, R. I. (2007). Perspective-taking and memory capacity predict social network size. Social Networks, 29(1), 93-104. https://doi.org/10.1016/j.socnet.2006.04.001

Thomson, W. (1994). Cooperative models of bargaining. Handbook of game theory with economic applications, 2, 1237-1284. https://doi.org/10.1016/S1574-0005(05)80067-0

Torgersen, S., Lygren, S., Øien, P. A., Skre, I., Onstad, S., Edvardsen, J., ... \& Kringlen, E. (2000). A twin study of personality disorders. Comprehensive psychiatry, 41(6), 416-425. https://doi.org/10.1053/comp.2000.16560

Warren, S. L., Huston, L., Egeland, B., \& Sroufe, L. A. (1997). Child and adolescent anxiety disorders and early attachment. Journal of the American Academy of Child \& Adolescent Psychiatry, 36(5), 637-644. https://doi.org/10.1097/00004583-199705000-00014 


\section{Biography of Authors}

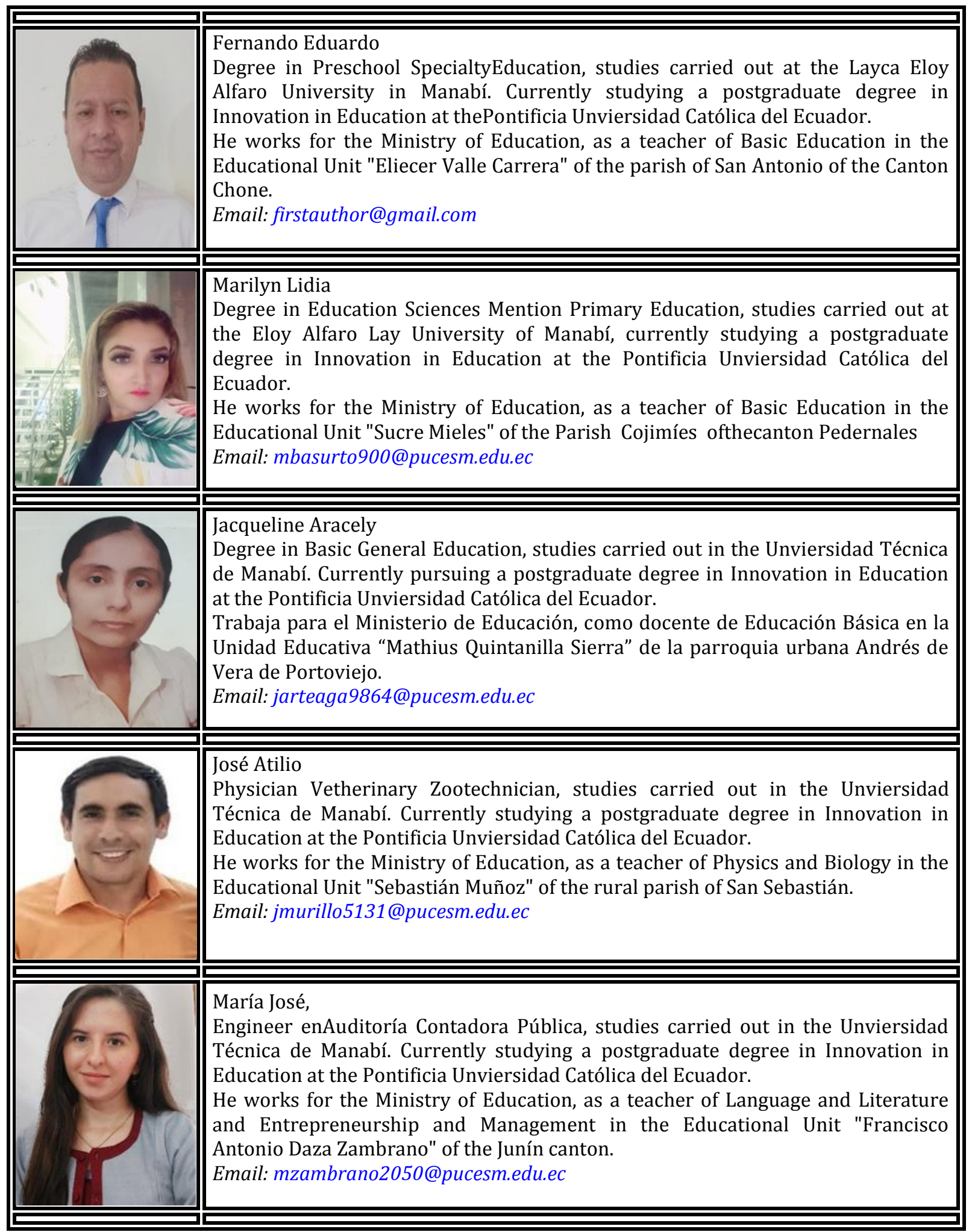

Rivas, F. E. C., Pilligua, M. L. B., Guerrero, J. A. A., Moreira, J. A. M., \& Zambrano, M. J. Z. (2021). Analysis of cooperative learning in adolescents with attention deficit. International Journal of Social Sciences and Humanities, 5(3), 253-263. https://doi.org/10.53730/ijssh.v5n3.2025 